\title{
Equity and Quality Analysis of Higher Education
}

\author{
Wanbo Yu ${ }^{1, \mathrm{a}}$, Li Zhang ${ }^{1, \mathrm{~b}}$ and Xudong Ren ${ }^{1, \mathrm{c}}$
}

\author{
${ }^{1}$ School of information, Dalian University, Dalian, Liaoning, China \\ ay__wb@126.com, ${ }^{b}$ zhangli@dlu.edu.cn, ${ }^{c} 767152581 @ q q . c o m$
}

\begin{abstract}
Discuss and analyze the educational fairness and quality issues in higher education, and suggest that universities should do their best, do their best, and make the best use of them. At the same time, a tentative suggestion is given for discussion. It is to regard colleges and universities as an economy and deepen the student loan system, so that those students with good quality but poor family economic status and bad cultural environment have the ability to complete their studies. Improve the unfairness of higher education, improve the quality of teaching and research in higher education institutions, use economic means to encourage schools to cultivate outstanding talents, and achieve breakthrough scientific research results. In addition, we discussed the implementation of the dual-level university program in the country. In the process of building a domestic first-class university, the newly born school has less resistance and hopes to join the ranks in the shortest time. In the process of improving the quality of education in colleges and universities, it is necessary to allocate resources reasonably, improve the enthusiasm of the teachers at school.
\end{abstract}

Keywords: higher education, educational equity, quality of education

\section{INTRODUCTION}

In recent years, the inequity of higher education and the quality of teaching and scientific research in colleges and universities have attracted wide attention from all walks of life as well as the Party and the government. One of the main phenomena of unfairness in higher education is that the quality of the source of enrollment (students) does not match the level of enrollment in higher education. In fact, some students have already lost in primary and junior middle schools, and some of them are creative, individualized and able to take on. The second is that some of the investments from the government and society have not been allocated reasonably and have not received the reward they deserve. For example, as mentioned in literature [1], some construction funds from the government have not been fully utilized, the scientific research funds have not been achieved the desired results, the education cost accounting policy does not match with the financial compensation, and some colleges and universities have not made the parents' funds and students' time and energy to achieve the desired results. Unfairness is directly related to the quality of colleges and universities. Unfairness makes it difficult to improve the quality, and the quality is not high, so that students can not get better training. After graduation, they do not have the skills and abilities to get a better career, so they do not go to university or graduate school. As mentioned in reference [2], the lack of procedural justice will seriously affect the selection of outstanding students in graduate enrollment. This makes some students with better quality but poor family economic condition and cultural environment stop in front of higher education. These result in passive injustice. However, reference [3] points out that the phenomenon of educational injustice has its own unique form of expression at the present stage in China, that is, the way of presentation is becoming more and more hidden and the scope of spread is becoming more and more basic, but it is of great significance to highlight the results and influence.

\section{THE DILEMMA OF HIGHER EDUCATION OUTCOMES}

One of the products of universities is students, and the other is scientific research achievements and their transformation. Both of them need time to verify the quality, and need to establish a complete evaluation index system to assess. At present, there are many doubts about the quality of colleges and universities in society, which comes from the dissatisfaction with these two "products". Many people pay attention to the employment of students and the level of students after graduation. In fact, we should pay more attention to the extent of students' improvement in University (or postgraduate period). It is a fair standard to evaluate the teaching quality of colleges and universities according to the extent of improvement, which should be taken as a guide. Under this standard, every university should rethink profoundly. The authenticity of scientific research achievements and their transformation must be guaranteed, and reasonable grade evaluation should be given. In fact, most of the scientific research achievements are only intermediate results. They are the research experience of students (master's and doctoral students), the exploration method of teachers, the expectation in perplexity and the assumption leading to success. Many achievements are often simple, beautiful and practical. Achieving these results requires not only hard work, incentives for remuneration, requirements for degrees, but also a calm mind, selfless vision, and, of course, a solid foundation and superb ability. What problems are worth exploring and how to shorten the research process are the key issues worth thinking about.

Everyone has a positive and upward nature, a desire to be recognized by society and others, and the right to use their own labor to obtain returns. In colleges and universities, because of the particularity of their two products, it is sometimes difficult to evaluate them, resulting in a very far-reaching negative impact. This has seriously affected the development of higher education. 


\section{PROBLEMS FACED BY PRIVATE COLLEGES}

The rise of private education to some extent has solved the difficult problem of going to university. However, at present, most private colleges can not get rid of such key difficulties as poor student resources and lack of excellent teachers. One of the reasons for this difficulty is the problem of funds. With the development of our economy, this problem will be gradually solved. At present, many research work has explored ways to solve the problem of low funding of private colleges and universities, such as university financing mentioned in document [4]. "The promulgation of the Law on the Promotion of Private Education" can improve the situation of private education, and its effect will be feedback in the future.

The main problem of private education is the "capital" problem. Private schools themselves are not able to solve this problem now. The so-called "capital" here is not only fixed assets, teachers, the number of students, media publicity, but also the credibility and reputation after precipitation, the latter has not been taken seriously by everyone. With the improvement of the quality of running a school, private colleges and universities will play their role in educational equity.

\section{THE APPROACH AND ADVANTAGES OF NEW MODEL}

Whether private colleges or puzzled public universities, they can try to use the successful experience of Tencent, Baidu and other companies to adopt a new model appropriately, with lofty aspirations, steer ahead and get out of the predicament. Tencent, Baidu and other companies first provide high-quality and free services, get the approval of the majority of users, and then get rewards under the premise of reasonable, fair and legal, and then further serve the society.

First of all, we should reverse our opinion, change our view, and dare to admit that we regard some schools or parts of schools as an enterprise, as a normal economic entity under the premise of ensuring its social service function. We should carefully plan the investment, scientifically construct the core of leadership, establish correct ideas for running schools, and train students to go hand in hand with the industrialization of scientific research. At present, in addition to private colleges and universities, some colleges and universities are exploring this new mode of running schools, new ideas, and have begun to implement.

Regarding the new model, we can adopt the unified examination plus independent enrollment. There is no limit to where students come from, which is similar to some universities abroad. In addition, we should promote and deepen student loan system, such as appropriate interest accrual or repayment in installments according to the percentage of post-work wages. That is to say, an incentive system can be established. If excellent talents are trained, the direct economic rewards will be greater. Of course, this requires careful investigation, analysis and submission of the government and relevant departments for formulation and approval.

This kind of loan system can also be piloted among primary and secondary school students. Now it is the state-funded, enterprise or individual donations to solve the problem of poor students' enrollment. Can we establish a mechanism to encourage students as a "product" and use economic means to solve the current educational equity and quality problems? Encourage the use of this model for "Taobao", multi-proactive search in (their professional direction) the development of students for training to obtain the benefits. University education can also consider infiltrating from primary and secondary schools, such as imitating art schools and establishing other professional secondary schools. This loan system is also described in the literature [5].

Recently, the country began to implement the "Double First-Class" university program, which is a meaningful work at this time. With regard to "Double First-Class" universities, literature [6] summarizes the three symbols of world-class universities: 1. Pursue excellence, 2. Lead development, 3. Global attractiveness; four characteristics are: 1.Headmasters are sensible, 2. Teachers are excellent, 3. Students are outstanding, 4. The funds are sufficient. In fact, this is just easy for a newborn school, especially the four characteristics. There is a sufficient reason to guess that a "Double First-Class" society in China comes from a new school.

\section{THERE ARE STILL MANY PROBLEMS TO BE SOLVED}

There is a lot of room for improvement in the quality of education in colleges and universities. Colleges and universities are not short of investment, but lack of many outstanding talents to devote themselves to the cause of education. Why not attract more outstanding talents to work in colleges and universities? You need to think about it. For example, it is pointed out in reference [7] that we need to further improve the higher education system and enrich the form of higher education. The enthusiasm of some school teachers needs to be improved, which needs to be solved by rational allocation of resources (including all kinds of funds), fair treatment of contributions and so on. In addition, there is the issue of professional title, the definition of professors and their responsibilities are not clear. Whether it is an honor or a responsibility; whether it is a reward for the past or an expectation for the future, it needs to be much clearer. Perhaps it is precisely because there is no clear responsibility and constraints, only wages and honors, so we all strive for it. Teachers who have no hope will no longer work hard. So we should find a way to solve these problems.

For teachers, students and funds, we must make the best use of our talents and resources.

Under the leadership and care of the Party and the government, through the efforts of all parties, education will be fair, and the quality of teaching will be greatly improved in the short term.

\section{ACKNOWLEDGMENT}

Thanks for the support of the Dalian University Graduate Education and Teaching Reform Fund (2018) and the Dalian University Education Reform Project Fund (2019). 


\section{REFERENCES}

[1] Guangmeng Gen, Guozhu Li, "Discussion on the Cost of Higher Education and Financial Compensation Mechanism [J]", Business economy, 2019-04-20.

[2] Zhiyuan Sun, Guozhu Qin, "Research on Graduate Enrollment Procedure from the Perspective of Procedural Justice [N]", Journal of Yangzhou University, 2019-02-20.

[3] Dandan Guo, "Research on the Mechanism of Educational Inequality--Based on the Perspective of Resource Allocation [J]", East China Normal University, 2019-03-10.

[4]Qingcheng Li, Leiyu Mo, "Ethical Appeal and Construction of Financing in Colleges and Universities [J]", China Higher Education, 2018(1),page:43-45.

[5] Shaowei Qu, Haoshi Wang, Jiaqi Shi, "Equity in Education in Big Countries: Retrospect and Prospect of China's Student Financial Aid Policy Reform in the Past 40 Years [J]", Institute of Educational Economics and Management, University of Science and Technology Beijing, 2018-11-25.

[6] Zhanjun Wang, Jing Liu, "Three Signs and Four Characteristics of World-class Universities [J]", China Higher Education, 2018(19),page:11-13.

[7] Luting Ma, "Develop fairer and more quality higher education [J]', Ministry of Education Education Development Research Center, 2019-03-18. 